Article

\title{
Potential of Waste Biomass from the Sugar Industry as a Source of Furfural and Its Derivatives for Use as Fuel Additives in Poland
}

\author{
Magdalena Modelska ${ }^{1}$, Michal J. Binczarski ${ }^{1}$, Piotr Dziugan ${ }^{2, *}$, Szymon Nowak ${ }^{3}$, \\ Zdzisława Romanowska-Duda ${ }^{4, * D}$, Adam Sadowski ${ }^{5}$ and Izabela A. Witońska ${ }^{1, *(\mathbb{D})}$ \\ 1 Institute of General and Ecological Chemistry, Faculty of Chemistry, Lodz University of Technology, \\ 90-924 Lodz, Poland; magdalena.modelska@dokt.p.lodz.pl (M.M.); michal.binczarski@p.lodz.pl (M.J.B.) \\ 2 Department of Environmental Biotechnology, Faculty of Biotechnology and Food Sciences, \\ Lodz University of Technology, 90-924 Lodz, Poland \\ 3 Branch of the National Sugar Company, "Polski Cukier" S.A. "DOBRZELIN Sugar Factory", \\ 99-319 Dobrzelin, Poland; szymon.nowak@polski-cukier.pl \\ 4 Department of Plant Ecophysiology, Faculty of Biology and Environmental Protection, University of Lodz, \\ 90-237 Lodz, Poland \\ 5 Faculty of Economics and Sociology, University of Lodz, 90-255 Lodz, Poland; adam.sadowski@uni.lodz.pl \\ * Correspondence: piotr.dziugan@p.lodz.pl (P.D.); zdzislawa.romanowska@biol.uni.lodz.pl (Z.R.-D.); \\ izabela.witonska@p.lodz.pl (I.A.W.)
}

Received: 9 November 2020; Accepted: 9 December 2020; Published: 17 December 2020

\begin{abstract}
Poland is one of the leading producers of sugar from sugar beet in Europe. However, the production of sugar generates large amounts of lignocellulosic waste, in the form of beet pulp and leaves. Currently, this waste is not reutilized in the chemical industry, but is only used as food for farm animals. This paper assesses the potential of using bio-waste from the sugar industry as a raw material for the production of furfurals via acid hydrolysis. Further processing of furfural into derivatives such as furfuryl alcohol (FA) or tetrahydrofurfuryl alcohol (THFA) could increase the economic profitability of the initiative. Furfuryl alcohol can be used as a fuel additive in sugar factories. Tetrahydrofurfuryl alcohol can be used as a component in agricultural fertilizers, increasing the yield of sugar beet. This approach reduces the amount of post-production waste and brings the sugar industry closer to the concept of a circular economy.
\end{abstract}

Keywords: furfural; furfuryl alcohol; tetrahydrofurfuryl alcohol; fuel additives; circular economy

\section{Introduction}

In response to increased social awareness, as well as to the tightening and more effective enforcement of environmental regulations, industry is switching its concept of production from that of a linear economy to one of a circular economy [1]. Environmental standards and regulations are encouraging entrepreneurs and scientists to develop such process models that allow for the use of waste in a closed cycle. One sector of the economy that generates large amounts of bio-waste is the agri-food industry. The production of finished products from agricultural crops generates large amounts of waste biomass, mainly consisting of cellulose, hemicellulose, and lignin, which has low potential for use as feed and constitutes a large-tonnage waste. Processing agro-waste into compost is one way of closing the loop. However, the disadvantage is the need to prepare an appropriate landfill and the length of time required to obtain the final product, which is neither highly valuable nor completely safe for the environment (due to the risk of introducing pathogens into the soil, for example). 
Another solution is to use waste biomass as a raw material in chemical processes. Biorefineries offer the most common example. Bioethanol can be produced by the fermentation of sugars obtained by biotechnological or chemical methods from the raw materials available in the region, such as sugar cane in Brazil or sugar beet in European countries. It can then be used as a fuel additive [2,3], or in manufacturing industries, for example as a base for the production of polymers [4]. The aim is that biorefineries, like refineries working on the basis of crude oil processing, should focus on producing a limited number of chemicals (about 20), which may be used as basic raw materials in chemical syntheses. Many of these base chemicals $[5,6]$ can be successfully obtained from biomass. One example is furfural, a platform chemical with great market potential [7-9]. New chemical products made from furfural can be used in the production cycle, e.g., as alternative fuels for power boilers or as liquid fuels in transport. They can also be used as construction materials or fertilizers, reducing the amount of waste produced and increasing the economic efficiency of the process. An example of such a solution is a biorefinery that produces ethanol, furfural, and electricity (Figure 1). In this solution, sucrose is used to produce bioethanol and the residual lignocellulosic biomass is converted into furfural and electricity. Although new biorefinery concepts based on biomass processing are being investigated [5,6], many of the proposed solutions have still not been implemented on an industrial scale.

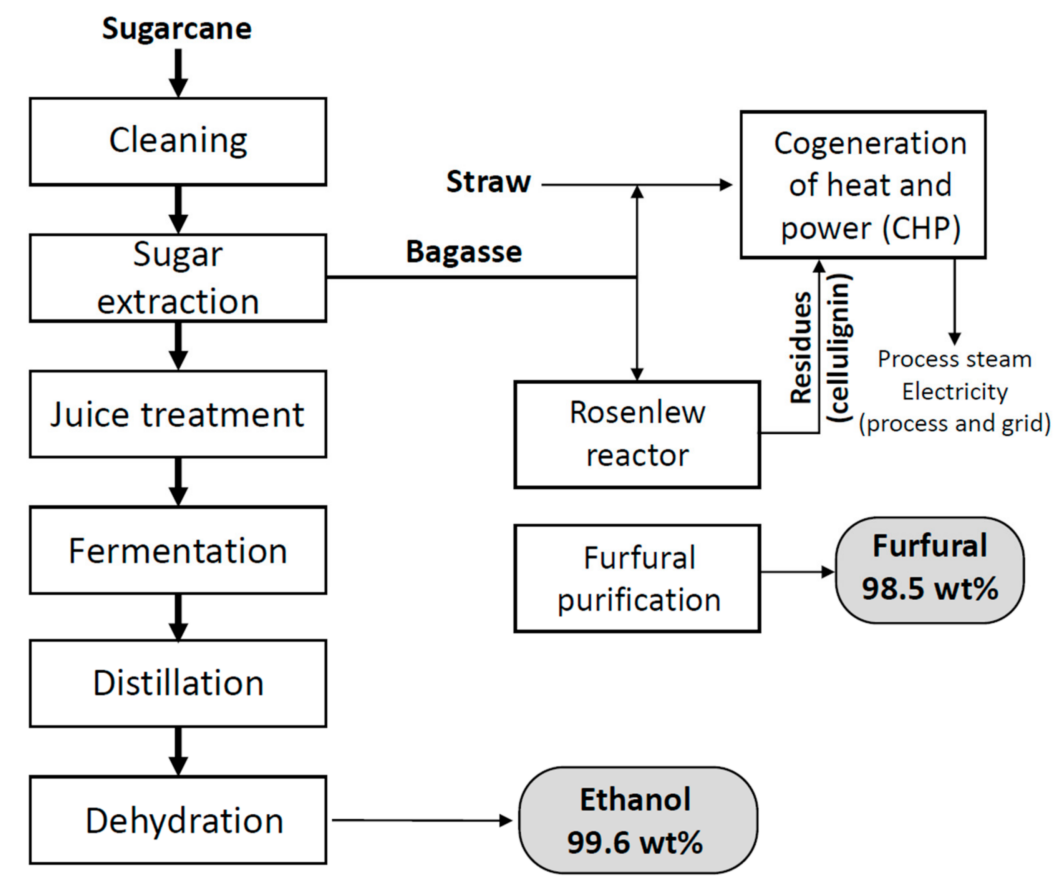

Figure 1. Block diagram of a bio-refinery producing ethanol, furfural, and electricity [7].

\section{Furfural}

Furfural is a golden, oily liquid with an almond-like odor. This compound has a carbonyl group and a system of conjugated double bonds in the ring, which allows it to be converted into chemical products including furfuryl alcohol, tetrahydrofurfuryl alcohol, furan, tetrahydrofuran, and alkanes [8-12]. Furfural does not mix with gasoline or diesel fuel. It is also chemically unstable and tends to polymerize. Its catalytic conversion products may be used as alternative fuels and fuel components. The octane number of furfural is 53. As a result of furfural reduction, products with a much higher octane number can be obtained, such as furfuryl alcohol (83), methylfuran (74), tetrahydrofurfuryl alcohol (83), or methyltetrahydrofuran (74) [13-15]. Fuel additives in the form of furfural derivatives work most effectively in low-octane hydrocarbon bases (hydrocracking gasoline), in amounts of 5-30 wt\%. High concentrations of furfural can promote the formation of resins in fuels, which are deposited in the combustion chamber of the engine. This issue requires more research [16]. 
It is estimated that the size of the global furfural market will grow from USD 551 million in 2019 to USD 700 million by 2024 [17]. The estimated cumulative annual growth rate is $11.6 \%[18,19]$. The most important raw materials for furfural production are corn cobs, which contain very large amounts of pentosans. Most furfural production plants use this raw material. The furfural market is expected to see the fastest growth of in the Asia-Pacific region. Already, this is the region with the highest production and consumption of furfural, led by China, which is expected to maintain its position in the furfural market. China produces over $80 \%$ of the world's furfural, and accounts for $72 \%$ of world consumption [13]. Other main producers of furfural include India and Thailand. Nonetheless, the furfural market is dominated by international companies, such as Transfuran Chemicals (Belgium), Central Romana Corporation (Dominican Republic), Pennakem (USA), Silvateam (Italy), Illovo Sugar (South Africa), Hongye Holding Group Corporation (China), KRBL (India), Lenzing (Austria), Tanin (Slovenia), and Shandong Crownchem Industries (China) [17].

According to statistical data published by the Central Statistical Office (GUS) in Warsaw in the Foreign Trade Base (BHZ) from 2004 to 2019 [20], the Polish furfural market is based entirely on imports. The size and value of the market for furfural and its derivatives results only from the level and structure of imports. On average, the domestic demand for furfural was $446,000 \mathrm{~kg} / \mathrm{year}$. The size of the market measured by the weight of imports for furfural over the period was $7,146,000 \mathrm{~kg}$, mainly from the European Union (over $98 \%$ by weight). Among the EU countries, the main importers to Poland are Austria (3,614,000 kg, 50.6\%), Slovenia (2,761,000 kg, 38.64\%), and Belgium (576,000 kg, 8.01\%). The furfural market in Poland is thus $97.3 \%$ dependent on imports from three countries: Austria, Slovenia, and Belgium. The analysis shows that the importance of Slovenia as an exporter to Poland of furfural is increasing. The remaining imports come from Spain, the Netherlands, Germany, Italy, and Great Britain. Another 1\% by weight is imported from other developed countries (Switzerland, South Africa, and United States of America). Less than 1\% of Poland's furfural by weight comes from developing countries, such as China, India, Dominica, the Dominican Republic, and Iran. The average annual value of imports in the analyzed period was 2,223,000 PLN. Over $98 \%$ of the value of these imports went to European Union countries, corresponding to the amount of imports by weight. In 2019, furfural prices were 6.65 PLN for Austria, 7.54 PLN for Slovenia, and 9.87 PLN for Belgium.

Given domestic demand, there is a clear interest in producing furfural in Poland, e.g., from agricultural waste biomass (corn cobs and straw) or waste from the food industry (spent grains, beet pulp and cereal bran). Currently, agriculture accounts for 3\% of Polish GDP. Agricultural land in Poland covers $18,608,000$ ha, which is $56 \%$ of Poland's territory. This places Poland in third place in Europe in terms of the share of land devoted to agriculture. The food industry is one of the few sectors of the economy that has a positive trade balance, which has steadily increased since Poland joined the European Union. This branch of industry (along with the tobacco industry) employs approximately 420,000 people on a full-time basis. This translates into around $18 \%$ of the labor force in manufacturing. In the years 2004-2018, the food industry experienced a growth rate in terms of output sold at current prices of on average 6.2\% per year [21]. According to data from the Central Statistical Office of Poland, in 2009 the mass of waste generated by agriculture and the agri-food industry in Poland was estimated at 10 million $\mathrm{Mg}$ (Table 1). The possibility of an accurate assessment is limited by the lack of information regarding waste from households and insufficient records. Importantly, some branches of the food industry work in campaign mode. This type of production generates very large amounts of waste in a single area in a short time [22]. 
Table 1. Percentage of unused raw material in various branches of food production [22].

\begin{tabular}{cc}
\hline Production Process & \% Weight of Raw Material Not Used in End Products \\
\hline Making Yoghurt & $2-6$ \\
Making Canned Fruit and Vegetables & $5-30$ \\
Making Canned Fish & $30-65$ \\
Making Fruit and Vegetable Juices & $30-50$ \\
Poultry Slaughter and Processing of Poultry Meat & $31-38$ \\
Pig Slaughter and Pork Processing & 35 \\
Cattle Slaughter and Beef Processing & $40-52$ \\
Manufacture of Vegetable Oils & $40-70$ \\
Manufacture of Corn Starch & $41-43$ \\
Making Fish Fillets, Salted Fish & $50-75$ \\
Wine Production & $20-30$ \\
Manufacture of Wheat Starch & 50 \\
Manufacture of Starch from Potatoes & 80 \\
Manufacture of Cheese & $85-90$ \\
Making Sugar from Sugar Beet & 86 \\
\hline
\end{tabular}

The current research suggests that bio-wastes such as bran obtained from grinding cereals (over $4 \mathrm{wt} \%$ ) and brewing spent grain (over $8 \mathrm{wt} \%$ under optimal reaction conditions) have the greatest potential for furfural production [23,24]. Various types of pomace from agro-food industries, such as from the production of fruit and vegetable juices or sugar production waste (beet pulp and sugar-beet leaves) also show good potential [25]. The advantage of processing waste from the agri-food industry into furfural is the possibility of using mobile installations at the point of waste generation. Despite the fact that the content of hemicellulose in various industrial wastes differs, the technology for converting biomass into furfural remains practically the same.

Sugar beet is one of the most important agricultural crops in Poland. Each year, approximately 14 million tons of sugar beet is produced in Poland, which is the third largest producer of sugar in Europe [26,27]. The main product of processing sugar beet is sugar (saccharose) [28]. However, after the extraction of saccharose, approximately 5 million tons of wet sugar beet pulp (SBP) or 1 million tons of dried biomass is also generated [25]. This agro-waste consists of polysaccharides (22-24 wt \% cellulose and $30 \mathrm{wt} \%$ hemicelluloses) and pectin (15-25 wt\%), with small amounts of fat $(1.4 \mathrm{wt} \%)$, protein $(10.3 \mathrm{wt} \%)$, ash $(3.7 \mathrm{wt} \%)$, and lignin $(5.9 \mathrm{wt} \%)$. Sugar beet pulp is used mainly as feed for farm animals, in the form of dry pellets or silage. Sugar beet leaves are another waste product, an estimated 8.5 million tons of which is produced in Poland each year. Sugar beet leaves are composed mainly of cellulose (13-18\%), hemicellulose (11-17\%), and pectin (14-18\%), with small amounts of lignin (5-6\%), as well as protein and ash [29-31]. Due to the lower nutritional value of this waste and the presence of saponins which cause cattle indigestion, beet leaves are used much less frequently as fodder. Sugar beet pulp and sugar beet leaves are attractive raw materials for the chemical and biotechnological industries. Hydrolysis of hetero-polysaccharides leads to the formation monosaccharides: xylose, glucose, mannose, galactose, rhamnose, and arabinose [32,33]. Hydrolysis of sugar beet pectin gives glucose, arabinose, and galacturonic acid, as well as smaller amounts of galactose and rhamnose [34-36]. The products from hydrolysis can be used as chemical raw materials or subjected to biological valorization.

Acidic hydrolysis is one of the most commonly-used methods for the chemical processing of biomass [37-43]. It is performed using a mineral acidic, such as sulfuric acid [37], hydrochloric acid [38], or phosphoric acid [39], or with organic acids, mainly dicarboxylic acids [40], in concentrations of $0.5-10 \%$. Elevated pressures and temperatures of $140-190{ }^{\circ} \mathrm{C}$ are usually required throughout the process [41-43]. As alternative to acids in aqueous phase heterogeneous catalysts may be used, which are sources of Brönsted and Lewis acid centers [44,45]. Biomass conversion over these acid centers can lead to various products, depending on the activated acid centers and the reaction conditions. One example is selective hydrothermal conversion of cellulose into lactic acid (LA), under mild reaction 
conditions in the presence of $\mathrm{ErCl}_{3}$ grafted onto mesoporous silica (MCM-41) [44]. This is also a very promising process the chemical industry, since like furfural LA is a platform molecule.

Acid hydrolysis of waste biomass from a variety of sources, including straw, bagasse, corncobs, oats, and wheat bran, can be used to produce furfural on an industrial scale. Due to their similar compositions, sugar beet leaves and pulp could also be used. Based on our previous research, we have established that furfural can be obtained from beet pulp with yields of about $4.5-5 \%$ and of $1.5-2 \%$ from sugar beet leaves (see Section 4 Results). If we assume that on average $40 \mathrm{~kg}$ of furfural can be obtained from 1 ton of beet pulp dry matter, the annual national demand in Poland for 448,438 kg of furfural would be covered by processing 11,211 tons of beet pulp dry matter, which is only $1.12 \%$ of the waste generated by the Polish sugar industry. Moreover, a single installation for processing dried beet pulp at one of the sugar factories in Poland would be sufficient cover domestic demand for furfural. One advantage of processing pulp biomass into furfural is the economic value added to the cost-free raw material, which can be increased by further steps leading to other chemical compounds (Figure 2) [46-48].

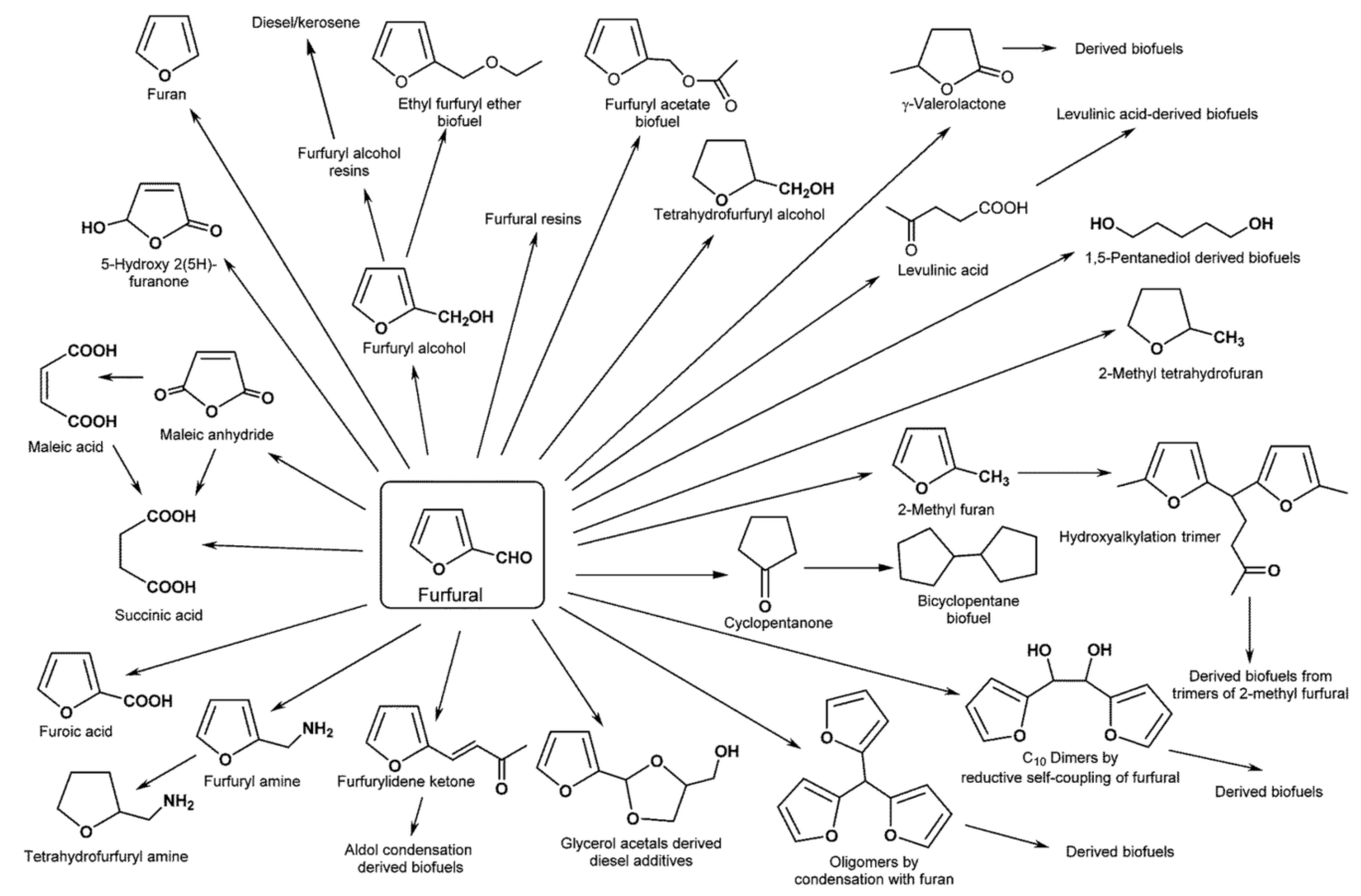

Figure 2. Furfural as a platform chemical [48].

A pilot installation for the processing of beet pulp and beet leaves into furfural on a quarter-technical scale has been built in the sugar factory in Dobrzelin (Figures 3 and 4). As part of the preparations for this installation, an initial profitability analysis was performed for the production of furfural on an industrial scale. The aim of the analysis was to determine the optimal scale of furfural production, guaranteeing a high return on the invested capital. The analysis was based on the discounted cash flow method and the following assumptions were made: (1) post-process waste from industrial plants belonging to KSC S.A. would be used for biomass hydrolysis (beet pulp from sugar factories); (2) the process would be powered mainly by waste heat and electricity from sugar factories; (3) sales revenues were estimated on the basis of the weighted average import price of furfuryl alcohol from the main import directions in 2019; (4) the weighted average cost of capital (discount rate) was 10\%; and (5) 24/7 production was assumed during the sugar campaign (100 days). The subsequent scenarios examined the impact of changes in the production of furfural on the value of discounted cash flows over a 10-year period. The results of the analysis are summarized in Table 2. 


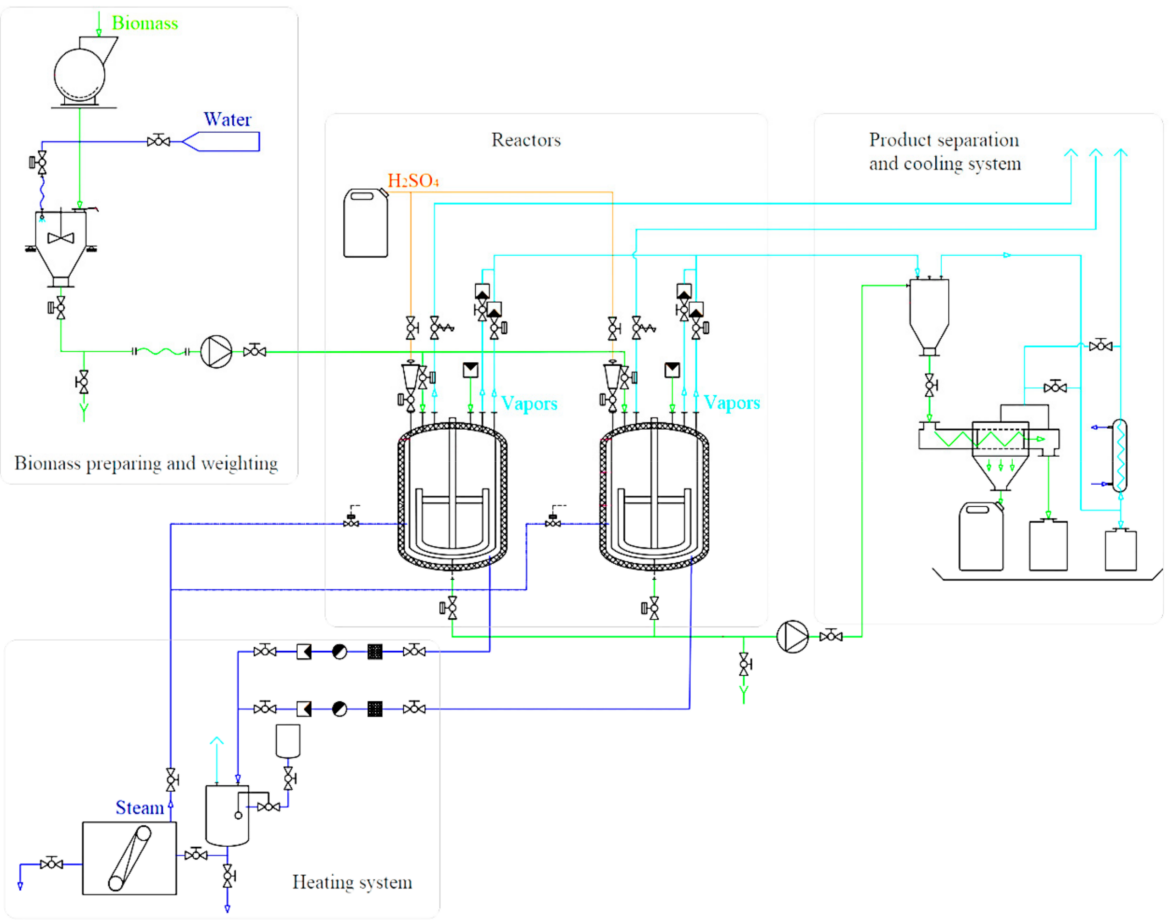

Figure 3. Diagram of an installation for the processing of beet pulp and beet leaves to furfural on a quarter-technical scale.

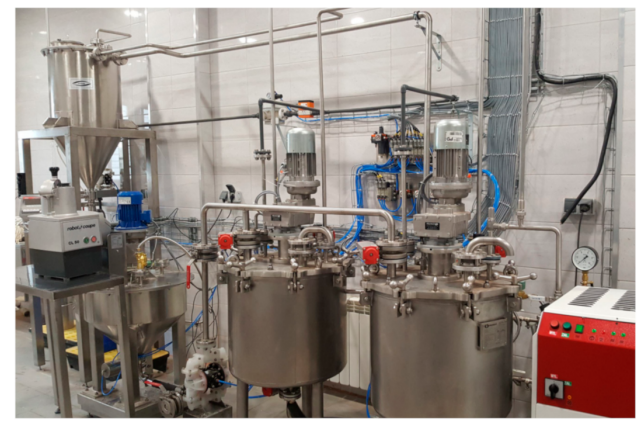

(a)

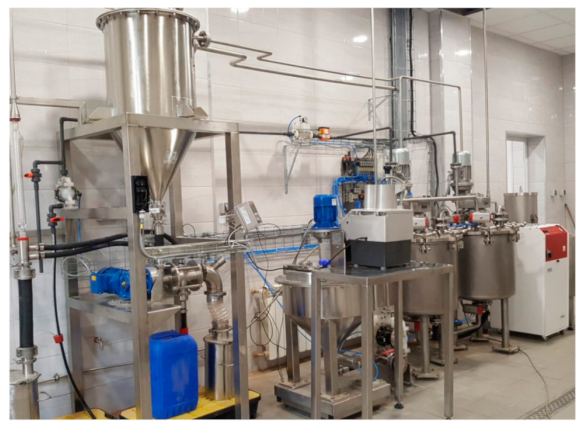

(b)

Figure 4. Photographs of an installation located in the sugar factory at Dobrzelin for processing beet pulp and beet leaves into furfural on a quarter-technical scale (a) right side view (b) left side view.

Table 2. Influence of changes in furfural production volume on the value of discounted cash flows over a 10 -year period.

\begin{tabular}{ccccc}
\hline \multicolumn{5}{c}{ Biomass Hydrolysis } \\
\hline Number of Reactors (cs) & $\mathbf{1}$ & $\mathbf{2}$ & $\mathbf{3}$ & $\mathbf{4}$ \\
\hline Reactors capacity $\left(\mathrm{m}^{3}\right.$ ) & 40 & 80 & 120 & 160 \\
Productivity of furfural/year (t) & 226 & 454 & 680 & 907 \\
Profitability analysis (PLN) & & \\
Estimated investment outlays & $5,000,000$ & $6,500,000$ & $8,000,000$ & $9,500,000$ \\
Sales revenue/year & $1,587,000$ & $3,175,000$ & $4,763,000$ & $6,350,000$ \\
Operating profit after tax (10 years) & 420,000 & $4,954,000$ & $9,480,000$ & $14,022,000$ \\
Net present value (NPV) of & $(-1,889,000)$ & 6000 & $1,902,000$ & $3,797,000$ \\
discounted cash flows (DCF) & & & & \\
\hline
\end{tabular}

The discounted cash flow method was used to calculate investment projections, assuming a $10 \%$ rate of return. The investment period was assumed to be 10 years and the calculations were made for the entire 10-year period. 
Based on the operation of the installation shown in Figure 3, a comprehensive assessment of the environmental impact of the manufactured product was performed, using the standardized life cycle assessment method (LCA). The LCA technique is based on the procedures described in ISO 14040 and 14044:

- PN-EN ISO 14040:2009 Environmental management. Life Cycle Assessment. Principles and structure. This standard covers the basic principles and structure of an LCA without describing the method in detail.

- PN-EN ISO 14044:2009 Environmental management. Life Cycle Assessment. Requirements and guidelines.

These standards describe the principles and structure of the LCA, as well as the requirements and procedures necessary for the assessment. Life Cycle Assessment traces the entire life cycle of a product, from its production to the stage of recovery or disposal, and seems to be a natural extension of both the waste management strategy and the environmental management system. The LCA showed that the greatest environmental impact was related to the heating and stirring of the pressurized reactor vessel for furfural production, accounting for almost $87 \%$ of the total impact. The impact of the electricity required for the production of furfural was calculated at $91.9 \%$ of all negative impacts. Increasing the size of the installation to the industrial scale could theoretically reduce the electricity requirement significantly, and its environmental footprint. For example, the energy used for heating and stirring the $40 \mathrm{~m}^{3}$ capacity autoclave account for $69.3 \%$ of the total negative impact. During the sugar campaign, waste heat from sugar processes could be used to heat the pressure reactors, significantly reducing the demand for electricity. This is another example of closing the energy cycle in the process.

An IPCC 2013 GWP 100a carbon footprint study was also conducted. Like the LCA analysis, it showed that the process would have a lower environmental impact on an industrial scale. Greenhouse gas emissions in equivalent $\mathrm{CO}_{2}$ were lower by approximately $42 \%$. Over $68 \%$ of the carbon footprint was due to the electricity use under laboratory conditions. Waste management processes accounted for $33.34 \%$ of the carbon footprint. On an industrial scale, electricity accounted for $38.83 \%$ of the carbon footprint, whereas the processing of waste accounted for $54.27 \%$. These results show the benefit of building a larger-scale installation for the production of furfural in a sugar factory.

Overall, the process of furfural production was found to have a large environmental impact. On the pilot scale, this amounted to $24.3 \%$ of all revenues. On the industrial scale, it would increase to $44.5 \%$. Our environmental impact study, including waste management, identified the following as the most important impact categories: climate change (from a human health and ecosystems perspective), human health toxicity, particulate formation, farmland use, and fossil fuel consumption. The greatest risk is to human health.

The following key conclusions can be drawn from the analysis: (1) given the assumed rate of return on capital and estimated investment outlays, to be profitable the capacity of the reactors for biomass hydrolysis should be at least $80 \mathrm{~m}^{3}$; (2) to increase profitability, the methods and costs of supplying the installation with renewable thermal energy beyond the period of the sugar campaign should be considered; and (3) the porous carbon material obtained by anaerobic combustion of the residues from hydrolysis can be used effectively to revitalize post-industrial areas and absorb pollutants from soil.

\section{Furfuryl Alcohol (FA) and Tetrahydrofurfuryl Alcohol (THFA)}

Furfural obtained as a result of acid hydrolysis of sugar waste can be further converted into more valuable chemical compounds, such as furfuryl alcohol (FA) and tetrahydrofurfuryl alcohol (THFA) (Figure 5). The most popular chemical compound obtained from furfural is furfuryl alcohol (FA), which is formed a result of hydrogenation of the furfural aldehyde group. The catalysts for the production of FA are based on copper, typically chromium-copper. The traditional method of 
producing FA by furfural reduction uses 110-gallon reactors and pressures of $68.9-103.4$ bar at $175^{\circ} \mathrm{C}$. More than $60 \%$ of the furfural produced annually is converted into FA $[10,49]$.

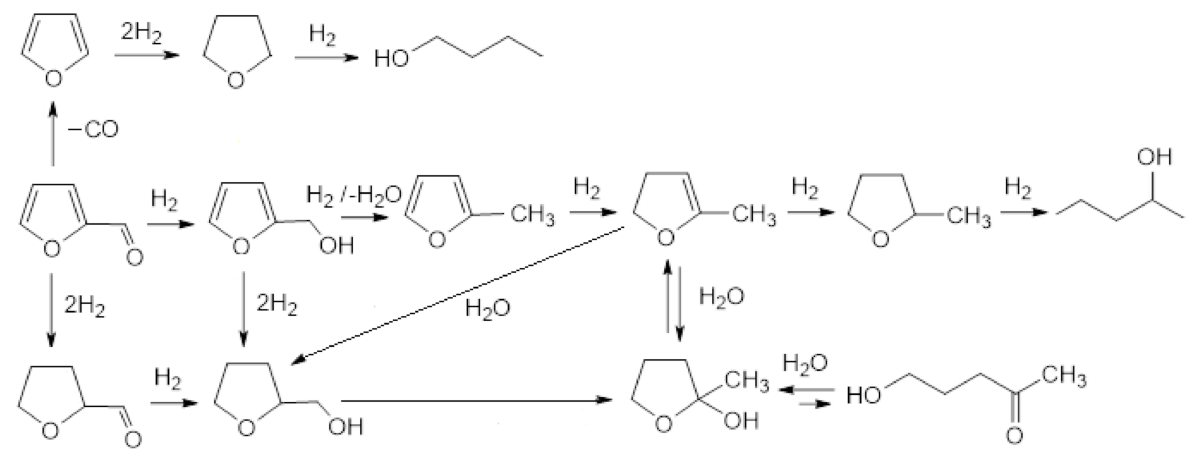

Figure 5. Main products of furfural reduction on metal catalysts in the water phase [47].

Furfuryl alcohol is used for the production of foundry resins, which have very good chemical, mechanical, and thermal properties. It is also used in the production of synthetic fibers, fragrances, paints, non-reactive thinners for epoxy resins, and modifiers of phenolic and urea resins, as well as for the production of other chemicals, e.g., THFA, coatings, selective solvents, adhesives, corrosion-resistant mortars, acid-resistant bricks, binders, impregnates, for laminating corrosion-resistant glass fiber devices, resins for polymers, furan concrete, and resins for gluing sand used for the preparation of cores and molds for casting metals. Furfuryl alcohol is also an intermediate used in the production of lysine, vitamin C, lubricants, dispersants, and plasticizers [10]. It can also be used as rocket fuel. Combined with an oxidant—white fuming nitric acid or fuming nitric acid—it forms a self-igniting mixture $[13,50]$. Another interesting way of processing FA is etherification with ethanol, which produces ethyl furfuryl ether (EFE). Production and use of EFE as a fuel has been patented by Shell. Ethyl furfuryl ether can be added to gasoline in amounts up to $30 \mathrm{wt} \%$. Due to its higher stability and octane number, EFE has advantages over FA as a fuel additive [48]. Furfuryl alcohol can also be converted into a mixture of $\mathrm{C}-\mathrm{C}$ coupled oligomers, which are subsequently hydrogenated to form a mixture of hydrocarbons with a tetrahydrofuran skeleton. The $\mathrm{C}_{9}-\mathrm{C}_{20}$ hydrocarbon fraction can be used as a component in kerosene and diesel fuel, whereas the higher fractions can, after being separated by distillation, be fed to a catalytic cracking or hydrocracking plant, and converted into diesel, kerosene, and gasoline fractions [48].

Further reduction of FA (or more precisely, reduction of the double bonds in the furan ring) yields THFA. Tetrahydrofurfuryl alcohol is known primarily as a "green" solvent (EPA approved). Its advantages include easy biodegradability, low toxicity, its ability to mix with polar and non-polar compounds, and very good penetration capacity. It is used in agriculture as a component of foliar fertilizers. It is also used widely in industry, as a component in industrial printing inks, in cleaning agents, and in electronics. It is a chemical intermediate for the pharmaceutical and chemical sectors. The largest producer of THFA is Koatsu Chemical Industries (Osaka, Japan), which produces around 30 tons of THFA every year. Under industrial conditions, THFA is produced in two stages. The first step is the reduction of furfural to FA, which is converted to THFA as a result of another catalytic reaction. In the process of reducing FA to THFA, noble metal-based systems are typically used as catalysts. Nickel catalysts are most often applied. Although these have worse catalytic properties than noble metals in reduction processes, they are significantly cheaper. The hydrogenation process takes place at temperatures of $50-100{ }^{\circ} \mathrm{C}$ in both the liquid and gas phase [10]. There are also reports in the literature describing the direct reduction of furfural to THFA, catalyzed systems including Pd/support, $\mathrm{Pd}-\mathrm{Cu} / \mathrm{Al}_{2} \mathrm{O}_{3}, \mathrm{Ni} /$ support, $\mathrm{Cu}-\mathrm{Ni} /$ support, and $\mathrm{WxC}-\beta-\mathrm{SiC}[49,51-57]$.

Tetrahydrofurfuryl alcohol has been successfully tested as a fuel additive. It allows ethanol to be mixed with diesel, resulting in a cleaner fuel [10]. Assuming diesel consumption of 200 billion gallons per year, the use of 80,000 metric tons of THFA could increase the ethanol added to diesel 
fuels to $10 \%$ [58]. The addition of biofuels such as levulinate esters to fuels requires an additional solvent. Tetrahydrofurfuryl alcohol can be used as this co-solvent, usually in amounts of 2-5 wt\%. [59]. A number of fuel additives can also be obtained from the oxidative conversion of tetrahydrofurfuryl alcohol. Some of the most attractive derivatives for this purpose are tetrahydrofurfuryl tertbutyl ether and acetal or ditetrahydrofurfuryl polyacetal. Compounds of this type can be used in diesel engines at low concentrations, as additives in standard diesel fuels or in fuels containing other additives such as alkyl esters from vegetable oils. The concentration of oxidized compounds in fuels can range from $0.01 \%$ to $1 \%$, with the optimal content being within the range of between $0.05 \%$ and $0.2 \mathrm{wt} \%$. Oxidized tetrahydrofurfuryl alcohol derivatives can also provide a base for diesel fuel. Used in this way, their content may be up to $40 \mathrm{wt} \%$, optimally $30 \mathrm{wt} \%$. Most often, however, oxidized THFA derivatives are added to fuels in amounts of $10-15 \mathrm{wt} \%$. Adding these derivatives to fuel does not preclude the use of other typical fuel additives and does not change their permissible content. Such fuel can power all types of diesel engines with indirect or direct fuel injection [60]. The addition of THFA also allows for the refinement of heavy crude oil, such as heavy oil, ultra-heavy oil, bitumen, heavy sour crude oil, and oil refinery heavy hydrocarbon residues. It is possible to use THFA as a cracking additive, distillation additive, and for hydrocarbon distillates obtained by the distillation of heavy crude oil in the presence of THFA [61].

Based on data provided by the Central Statistical Office [20], it can be concluded that the Polish market for FA and THFA, is currently based on imports, with no domestic production. Exports in the period 2004-2019 amounted to $133 \mathrm{~kg}$, which is insignificant. Moreover, the exported alcohol was not made in Poland. The main export destinations were Belarus, Ukraine, Lithuania, and Slovakia. It can be assumed therefore that the economic value of the market corresponds to the statistical data relating to the level and structure of imports. The size of the market, measured by the weight of net imports for FA and THFA in the studied period (2004-2019), was 12,951,000 kg, while the average domestic demand for FA and THFA was 809,438,000 kg/year. The greatest recorded demand was 1,032,000 kg in 2014. In the analyzed period, the market was entirely shaped by imports from three locations:

- from developing countries-694,478,000 kg, which was $5.36 \%$ of the total mass. China was the only developing country that supplied furfuryl and tetrahydrofurfuryl alcohol.

- from other developed countries-4,827,918,000 kg, which constituted $37.28 \%$ of the total mass. The main importer in this group of countries was South Africa, supplying $97.75 \%$ by weight. The remaining imports came from countries such as Switzerland, Canada, Norway, and the United States of America.

- from the European Union-7,428,604,000 kg, which constituted $57.36 \%$ of the total weight. Among the EU countries, Belgium was the main importer, supplying $91.51 \%$ of imports from EU countries. Other imports came from countries such as Austria, the Netherlands, France, Germany, Italy, and the United Kingdom.

The list of countries that currently export to Poland includes Belgium, Italy, Great Britain, Ukraine, Tunisia, Switzerland, the United States, Slovakia, Russia, South Africa, Norway, Germany, Moldova, Lithuania, Canada, the Netherlands, Georgia, France, and China. However, in 2019 the largest exporters of FA and THFA were still Belgium, China, South Africa, and the Netherlands. The Polish market for furfuryl and tetrahydrofurfuryl alcohol thus very much depends on imports from Belgium and South Africa, and to a lesser extent from China. Since 2012, the importance of South Africa has been decreasing in favor of China.

The market value for FA and THFA in the years 2004-2019 corresponding to the volume of imports amounted to PLN 80,932,000. The average annual value of imports in the analyzed period was PLN $5,058,000$. The largest value of imports was recorded for Belgium, at PLN 42,747,000 (52.8\%), and for the Republic of South Africa, at PLN 27,339,000 (33.8\%). The share of Chinese imports in the analyzed period amounted to PLN 5,127,000 (6.3\%). Prices per kilogram in 2019 were as follows: for imports 
from Belgium PLN 6.29; from South Africa PLN 5.79; from China PLN 7.38. It can be assumed that the high level of imports from Belgium results from price competition.

The research and development carried out by the authors so far under the BIOSTRATEG2/ 296369/5/NCBR/2016 project indicate the possibility of expanding furfural production by catalytic reduction to FA or THFA, depending on the catalyst used $[16,36,37,39,42,43,46]$. The direct production of THFA from furfural may be the most advantageous, from the point of view of the low toxicity of the product. The THFA could then be used as an ingredient in foliar fertilizers for sugar beet plantations, closing this material cycle in the production of sugar from sugar beet. Such closing of loops is essential to realizing the concept of a circular economy in sugar processes.

\section{Results}

Table 3 presents furfural yields obtained in the processes of acid hydrolysis of beet pulp and sugar beet leaves in a quarter-technical installation built in the Sugar Plant in Dobrzelin. Average yields of furfural from beet pulp are approximately $4.5 \%$ when the process is carried out at $120{ }^{\circ} \mathrm{C}$ in an environment of $0.5 \% \mathrm{H}_{2} \mathrm{SO}_{4}$ under increased pressure (resulting from raising the temperature in a closed system). The yields of furfural from the sugar beet leaf hydrolysates were less than half those for beet pulp under the same conditions, at below $2 \%$. The efficiency of furfural production was taken into account when calculating the profitability of an industrial-scale installation in a sugar factory.

Table 3. Influence of material and processing parameters on the efficiency of furfural production on a quarter-technical scale at the Dobrzelin Sugar Plant.

\begin{tabular}{|c|c|c|c|c|c|c|c|c|}
\hline $\begin{array}{c}\text { Raw } \\
\text { Material }\end{array}$ & $\begin{array}{c}\text { Dry } \\
\text { Matter } \\
(\%)\end{array}$ & $\begin{array}{c}\text { Raw Material } \\
\text { Weight (kg) } \\
\text { (Dry Matter of } \\
\text { Raw Material } \\
\text { (kg)) }\end{array}$ & $\begin{array}{c}\text { Water } \\
\text { Weight } \\
\text { (kg) }\end{array}$ & $\begin{array}{c}\mathrm{H}_{2} \mathrm{SO}_{4} \\
\text { Conc. } \\
(\%)\end{array}$ & $\begin{array}{l}\text { Time } \\
\text { (h) }\end{array}$ & $\begin{array}{c}\text { Temp. } \\
\left({ }^{\circ} \mathrm{C}\right)\end{array}$ & $\begin{array}{c}\text { Furfural } \\
\text { Conc. } \\
\text { (g/kg) }\end{array}$ & $\begin{array}{l}\text { Yield of } \\
\text { Furfural } \\
(\%)\end{array}$ \\
\hline \multirow{5}{*}{$\begin{array}{c}\text { Sugar } \\
\text { Beet Pulp }\end{array}$} & 19.71 & $10(1.971)$ & 50 & 0.5 & 2 & 140 & 1.596 & 4.86 \\
\hline & 19.71 & $10(1.971)$ & 50 & 2.0 & 2 & 140 & 1.754 & 5.34 \\
\hline & 23.34 & $10(2.334)$ & 50 & 5.0 & 2 & 140 & 2.136 & 5.49 \\
\hline & 23.34 & $10(2.334)$ & 50 & 0.5 & 2 & 120 & 1.762 & 4.53 \\
\hline & 19.71 & $20(3.942)$ & 40 & 0.5 & 2 & 140 & 2.286 & 3.48 \\
\hline \multirow{5}{*}{$\begin{array}{c}\text { Sugar } \\
\text { Beet } \\
\text { Leaves }\end{array}$} & 11.75 & 10 (1.175) & 50 & 0.5 & 2 & 160 & 0.497 & 2.53 \\
\hline & 11.75 & 10 (1.175) & 50 & 0.5 & 2 & 140 & 0.359 & 1.83 \\
\hline & 11.75 & 10 (1.175) & 50 & 0.5 & 2 & 120 & 0.298 & 1.52 \\
\hline & 11.75 & 10 (1.175) & 50 & 2.0 & 2 & 140 & 0.467 & 2.38 \\
\hline & 11.75 & $20(2.350)$ & 40 & 0.5 & 2 & 140 & 0.496 & 1.27 \\
\hline
\end{tabular}

Table 4. shows the results of the catalytic reduction of commercial furfural in an aqueous solution $\left(C_{0}=0.1 \mathrm{~mol} / \mathrm{dm}^{3}\right)$ and of solutions with the same concentration of furfural prepared from pulp hydrolysates and sugar beet leaves. Neutralized hydrolysates initially concentrated by membrane nanofiltration (FILMTEC Membranes NF270-2540) to a concentration of approximately $0.25 \mathrm{~mol} / \mathrm{dm}^{3}$ were used to prepare the reaction solutions. The results of the catalytic reduction of the aqueous solutions of furfural obtained by acid hydrolysis of beet pulp and beet leaves indicate the high potential of this method for the production of furfuryl alcohol and tetrahydrofurfuryl alcohol from waste biomass. The use of $5 \% \mathrm{Pd} / \mathrm{Al}_{2} \mathrm{O}_{3}$ catalysts leads mainly to the production of tetrahydrofurfuryl alcohol, whereas use of the $5 \% \mathrm{Cu} / \mathrm{Al}_{2} \mathrm{O}_{3}$ catalyst only results in the selective reduction of the carbonyl group of furfural, preserving the double bonds in the furan ring. Our results are consistent with previously performed catalytic tests of model reactions [49]. 
Table 4. Reduction of furfural over $5 \% \mathrm{Cu} / \mathrm{Al}_{2} \mathrm{O}_{3}$ and $5 \% \mathrm{Pd} / \mathrm{Al}_{2} \mathrm{O}_{3}$ catalysts.

\begin{tabular}{cccccccc}
\hline & \multicolumn{3}{c}{$\mathbf{5 \%} \mathbf{C u} / \mathbf{A l}_{\mathbf{2}} \mathbf{O}_{\mathbf{3}}$} & \multicolumn{3}{c}{$\mathbf{5 \%} \mathbf{\mathbf { P d } _ { \mathbf { A } }} \mathbf{A l}_{\mathbf{2}} \mathbf{O}_{\mathbf{3}}$} \\
\cline { 2 - 7 } Furfural & $\mathbf{X}$ & $\mathbf{S}_{\mathrm{FA}}$ & $\mathbf{S}_{\mathrm{THFA}}$ & $\mathbf{X}$ & $\mathbf{S}_{\mathrm{FA}}$ & $\mathbf{S}_{\mathrm{THFA}}$ \\
& $\mathbf{( \% )}$ & $\mathbf{( \% )}$ & $\mathbf{( \% )}$ & $\mathbf{( \% )}$ & $\mathbf{( \% )}$ & $\mathbf{( \% )}$ \\
\hline Commercial & 81 & 100 & 0 & 100 & 28 & 72 \\
From sugar beet pulp hydrolysate & 90 & 100 & 0 & 100 & 31 & 69 \\
From sugar beet leaves hydrolysate & 78 & 100 & 0 & 100 & 26 & 74 \\
\hline
\end{tabular}

Activation of catalysts: drying in air at $110{ }^{\circ} \mathrm{C}, 6 \mathrm{~h}$; oxidation in $\mathrm{O}_{2}$ at $500{ }^{\circ} \mathrm{C}, 2 \mathrm{~h}$; reduction in $\mathrm{H}_{2}$ at $300{ }^{\circ} \mathrm{C}, 2 \mathrm{~h}$. Reaction conditions: $\mathrm{T}=90^{\circ} \mathrm{C}, \mathrm{m}_{\text {cat }}=0.5 \mathrm{~g}, \mathrm{~V}_{\text {furfural }}=25 \mathrm{~mL}, \mathrm{C}_{\text {furfural }}=0.1 \mathrm{M}, \mathrm{pH}_{2}=20$ bar.

\section{Materials and Methods}

\subsection{Lignocellulosic Plant Material}

The lignocellulosic plant raw materials used for the production of furfural by acid hydrolysis were sugar beet pulp and beet leaves. These wastes were obtained from a sugar factory located in Dobrzelin, during the sugar campaigns of 2019 and 2020. We first determined the amount of dry matter in raw material, using a Radwag MA 50.r moisture analyzer with IR radiator (Radwag, Radom, Poland). The raw material was then subjected to acidic hydrolysis processes.

\subsection{Acidic Hydrolysis of Biomass}

Hydrolysates containing furfural were obtained by acidic hydrolysis of sugar beet pulp and sugar beet leaves in the semi-industrial installation shown in Figures 3 and 4. Biomass hydrolysis was performed in a pressure reactor with a volume of $75 \mathrm{dm}^{3}$, at a temperature of $120-160{ }^{\circ} \mathrm{C}$. Prior to each reaction, $10-20 \mathrm{~kg}$ of fragmented biomass and $40-50 \mathrm{~kg}$ of water $\left(60^{\circ} \mathrm{C}\right)$ was weighed in the homogenizer (a steel tank with a stirrer) resting on technical scales. After loading the biomass and water, the agitator was turned on to ensure even mixing of the mixture. The contents of the tank were then pumped into the $75 \mathrm{dm}^{3}$ pressure reactor using a peristaltic pump. Concentrated $\mathrm{H}_{2} \mathrm{SO}_{4}$ (analytical grade, 95\%, P.P.H. "Stanlab" sp. j., Lublin, Poland) corresponding to $0.5-5 \%$ by weight of the reaction mixture was introduced into the reactor by an automatic system and the reactor was heated with steam from a steam generator. The start of the hydrolysis process was considered to be the moment when the reaction mixture reached the desired temperature, and typically lasted for $0.5 \mathrm{~h}$. After the reaction run, the reaction mixture was cooled in the reactor to $80^{\circ} \mathrm{C}$ and the gaseous products were discharged from the reactor first through the cooling system. Once the pressure was equalized, the reaction mixture was pumped using a diaphragm pump into the separation system, where the hydrolysate and solid residues were separated. Samples of the hydrolysates were then neutralized by the addition of $\mathrm{CaCO}_{3}\left(\mathrm{CaCO}_{3}\right.$, analytical grade, $\mathrm{POCh}$, Gliwice, Poland) to $\mathrm{pH}$ 6-7. After filtration on syringe filters, the hydrolysates were subjected to chromatographic analysis for furfural content (see Section 5.3) and used as a substrate in reduction processes.

\subsection{Catalytic Reduction of Furfural}

Hydrogenation of the aqueous furfural solution $\left(0.1 \mathrm{M}, 0.025 \mathrm{dm}^{3}\right.$, commercial: $\mathrm{POCH}$, pure or prepared by acidic hydrolysis of sugar beet pulp and sugar beet leaves) was conducted in a $0.050 \mathrm{dm}^{3}$ autoclave (Parr Instrument Company, Moline, IL, USA) at $90{ }^{\circ} \mathrm{C}$ and 20 bar hydrogen pressure. Equal amounts of home-made catalysts $5 \% \mathrm{Pd} / \mathrm{Al}_{2} \mathrm{O}_{3}$ or $5 \% \mathrm{Cu} / \mathrm{Al}_{2} \mathrm{O}_{3}[49]\left(\mathrm{m}_{\text {cat }}=0.5 \mathrm{~g}\right)$ were used in each reaction. The catalyst suspended in liquid reactants was mixed at $500 \mathrm{rpm}$. Further increases in mixing speed no longer resulted in changes in activity, ensuring that the reaction proceeded within the kinetic area (diffusion restrictions were eliminated). To remove the air, the autoclave was flushed with argon (Ar, Linde 5.0, $0.020 \mathrm{dm}^{3} \cdot \mathrm{min}^{-1}$, at $20^{\circ} \mathrm{C}$, for $15 \mathrm{~min}$ ). After $15 \mathrm{~min}$, hydrogen was passed through the autoclave $\left(\mathrm{H}_{2}\right.$, Air Products, Premium Plus, $99.999 \%$, at $\left.20{ }^{\circ} \mathrm{C}\right)$ for about $15 \mathrm{~min}$. The system was then closed. The $\mathrm{H}_{2}$ pressure was raised to $20 \mathrm{bar}$ and the temperature was increased 
to $90{ }^{\circ} \mathrm{C}$, using a linear temperature rise of $20^{\circ} \mathrm{C} \cdot \mathrm{min}^{-1}$. After reaching the desired temperature and pressure, the process was continued for $2 \mathrm{~h}$. Reaction conditions were optimized for mono- and bimetallic palladium catalysts. The qualitative and quantitative composition of the reaction mixture was analyzed using a dual-channel gas chromatography system with FID and quadrupole MS detector and a SHIMADZU liquid sample feeder QP-2010 SE equipped with two SPL dispensers (GCMS-QP2010 $\mathrm{SE})$. Separation of the analyte components was performed independently on two of the same columns (Zebron ZB-5MSplus Capillary GC Column $30 \mathrm{~m} \times 0.25 \mathrm{~mm} \times 0.25 \mu \mathrm{m}$ PHX-7HG-G030-11) connected to FID and MS detectors (sample volume $1 \mu \mathrm{L}$; injector temperature $200^{\circ} \mathrm{C}$; furnace operation: initial temperature $50^{\circ} \mathrm{C}$ for $5 \mathrm{~min}$, heating with a linear increase of $5{ }^{\circ} \mathrm{C} / \mathrm{min}$ to $150{ }^{\circ} \mathrm{C}$ and thermostating at $150^{\circ} \mathrm{C}$ for $5 \mathrm{~min}$ ). Quantitative analysis of furfural, furfuryl alcohol, and tetrahydrofurfuryl alcohol was performed on the basis of the calibration curve for a range of glucose concentrations of $0-10 \mathrm{~g} / \mathrm{dm}^{3}$ (the curves in the analyzed range were linear for all compounds: furfural: $y=9834.464 x-40,630.07$, $\mathrm{R}^{2}=0.9998569, \mathrm{R}=0.9999285 ;$ furfuryl alcohol; $\mathrm{y}=5759.799 \mathrm{x}-105,940.5, \mathrm{R}^{2}=0.998118, \mathrm{R}=0.9990586$; tetrahydrofurfuryl alcohol: $y=13,478.67 x-253,621.9, R^{2}=0.9999688, R=0.9999844$ ).

\section{Conclusions}

This paper has presented the acid hydrolysis of beet pulp and sugar beet leaves, performed on a quarter-technical scale in a sugar factory in Dobrzelin. The results indicate the great potential of this method for the production of furfural. The average yield of furfural from beet pulp was $4.5-5 \%$, and from sugar beet leaves about $1.5-2 \%$. Based on the initial outlay and operating costs required for the quarter-technical scale installation, the profitability of a full industrial-scale installation for furfural production from sugar waste was estimated. The discounted cash flow method was used for the projections, assuming a 10\% rate of return and a 10-year investment period. Four technological variants were considered, assuming the operation of between one and four reactors with a capacity of $40 \mathrm{~m}^{3}$ each. It was found that the optimal variant is an installation consisting of three hydrolysers working on a charge of beet pulp.

Poland is the leading producer of sugar from sugar beet in Europe. As a result of the processing of sugar beet, large amounts of lignocellulosic waste in the form of beet pulp and beet leaves are generated, which can be successfully used for the production of furfural in amounts covering domestic demand. Further processing of furfural into less toxic derivatives, such as tetrahydrofurfuryl alcohol, could contribute to increase the profitability of the process and also lead to a reduction in the negative environmental impact of the manufactured product. Tetrahydrofurfuryl alcohol can be successfully used as a component in agricultural fertilizers, increasing the yield of sugar beet plants. This approach reduces the amount of post-production waste and contributes to the closing of material cycles, bringing the sugar industry closer to the concept of a circular economy.

Author Contributions: Conceptualization, A.S., Z.R.-D. and I.A.W.; writing-original draft preparation, I.A.W., M.M., S.N. and M.J.B.; writing-review and editing, I.A.W., Z.R.-D. and A.S.; visualization, M.M., S.N. and M.J.B.; project administration: P.D. and I.A.W. All authors have read and agreed to the published version of the manuscript.

Funding: This research was funded by The National Centre for Research and Development under Project BIOSTRATEG2/296369/5/NCBR/2016.

Conflicts of Interest: The authors declare no conflict of interest.

\section{References}

1. EU. Communication of the European Commission on Integrated Product Policy; EU: Brussels, Belgium, 2003; Volume 302.

2. Tao, L.; Aden, A. The economics of current and future biofuels. In Vitro Cell. Dev. Biol. Plant 2009, 45, $199-217$. [CrossRef]

3. Hira, A. Sugar rush: Prospects for a global ethanol market. Energy Policy 2011, 39, 6925-6935. [CrossRef] 
4. Bos, H.L.; Meesters, K.P.H.; Conijn, S.G.; Corre, W.J.; Patel, M.K. Accounting for the constrained availability of land: A comparison of bio-based ethanol, polyethylene, and PLA with regard to non-renewable energy use and land use. Biofuels Bioprod. Biorefin. 2012, 6, 146-158. [CrossRef]

5. De Jong, W.; Marcotullio, G. Overview of biorefineries on co-production of furfural, existing concepts and novel developments. Int. J. Chem. Reactor Eng. 2010, 8, A69. [CrossRef]

6. Moulijn, J.A.; Makkee, M.; Van Diepen, A.E. Chemical Process Technology, 2nd ed.; John Wiley \& Sons: Chichester, UK, 2012.

7. Silva, J.F.L.; Selicani, M.A.; Junqueira, T.L.; Klein, B.C.; Vaz Junior, S.; Bonomi, A. Integrated furfural and first generation bioethanol production: Process simulation and technoeconomic analysis. Braz. J. Chem. Eng. 2017, 34, 623-634. [CrossRef]

8. Shittu, A. Catalytic Conversion of Hemicellulosic Sugars into Furfural in Ionic Liquid Media. Master's Thesis, The University of Toledo, Toledo, OH, USA, 2010.

9. Win, D.T. Furfural-Gold from Garbage. AU J. Technol. 2005, 8, 185-190.

10. Yan, K.; Wu, G.; Lafleur, T.; Jarvis, C. Production, properties and catalytic hydrogenation of furfural to fuel additives and value-added chemicals. Renew. Sus. Energy Rev. 2014, 38, 663-676. [CrossRef]

11. Huber, G.W.; Chheda, J.N.; Barrett, C.J.; Dumesic, J.A. Production of liquid alkanes by aqueous-phase processing of biomass derived carbohydrates. Science 2005, 308, 1446-1450. [CrossRef]

12. Xu, W.; Xia, Q.; Zhang, Y.; Guo, Y.; Wang, Y.; Lu, G. Effective Production of Octane from Biomass Derivatives under Mild Conditions. ChemSusChem 2011, 4, 1758-1761. [CrossRef]

13. Malinowski, A.; Wardzińska, D. Katalityczna konwersja furfuralu do biokomponentów paliwowych. Chemik 2012, 66, 982-990.

14. Huber, G.W.; Iborra, S.; Corma, A. Synthesis of transportation fuels from biomass: Chemistry, catalysts, and engineering. Chem. Rev. 2006, 106, 4044-4098. [CrossRef]

15. Dong, S.Y.; Shi, Q.L.; Ma, Y.S.; Mou, Q.P.; Zhang, J.L.; Luan, B. Gasoline Octane Number Enhancer and Preparation Method Thereof. CN102746919A, 24 October 2012.

16. Nikul'shin, P.A.; Ershov, M.A.; Grigor'yeva, E.V.; Tarazanov, S.V.; Kuzentsova, S.N.; Repina, O.V. Furfural derivatives as fuel components. Chem. Tech. Fuels Oil 2020, 55, 720-725. [CrossRef]

17. Furfural Market by Raw Material (Sugarcane Bagasse, Corncob, Rice Husk and Others), Application (Derivatives (Furfural Alcohol and Other Derivatives), Solvent) and Region (Asia-Pacific, Americas, Europe, Middle East and Africa)_Global Forecast to 2024; Report ID: 4847017; Research and Market: Dublin, Ireland, 2019.

18. Allied Market Research, Furfural Market Report. Available online: https://www.alliedmarketresearch.com (accessed on 11 October 2017).

19. Clauser, N.M.; Gutiérez, S.; Area, M.C.; Felissia, F.E.; Vallejos, M.E. Techno-economic assessment of caroxylic acids, furfural, and pellet production ion a pine sawdust biorefinery. Biofuels Bioprod. Bioref. 2018, 12, 997-1012. [CrossRef]

20. Polish Central Statistical Office. Foreign Trade Database from 2004-2016; Polish Central Statistical Office: Warsaw, Poland, 2017.

21. Ministry of Agriculture and Rural Development. Rolnictwo i Gospodarka Żywnościowa w Polsce, Collective Work Edited by the Institute of Agricultural and Food Economics; Institute of Agricultural and Food Economics: Warsaw, Poland, 2019.

22. Daniel, Z.; Juliszewski, T.; Kowalczyk, Z.; Malinowski, M.; Sobol, Z.; Wrona, P. Metoda szczegółowej klasyfikacji odpadów z sektora rolniczego i rolno-spożywczego. Infrastrukt. Ekol. Terenów Wiej. 2012, 2/IV, 141-152.

23. Modelska, M.; Binczarski, M.; Dziugan, P.; Karski, S.; Witońska, I. Furfural obtained from waste biomass as a substrate in selective furfuryl alcohol catalytic production. In Proceedings of the 4th International Conference Sustainable Postharvest and Food Technologies-INOPTEP and 27th National Conference Processing and Energy in Agriculuture-PTEP, Divčibare, Serbia, 19-24 April 2015; pp. 165-169.

24. Modelska, M.; Binczarski, M.; Dziugan, P.; Karski, S.; Witońska, I. From industrial waste biomass to valuable chemical compounds. In Proceedings of the 29th EFFoST Conference Food Science Research and Innovation: Delivering Sustainable Solutions to the Global Economy and Society, Athens, Greece, 10-12 November 2015; Volume I, pp. 237-242. 
25. Modelska, M.; Berlowska, J.; Kręgiel, D.; Cieciura, W.; Antolak, H.; Tomaszewska, J.; Binczarski, M.; Szubiakiewicz, E.; Witońska, I. Concept for recycling waste biomass from the sugar industry for chemical and biotechnological purposes. Molecules 2017, 22, 1544. [CrossRef]

26. Produkcja Cukru w Polsce, Kampania 2019/2020. Available online: http://www.agroindustry.pl/index.php/ 2020/04/07/produkcja-cukru-w-polsce-kampania-20192020/ (accessed on 18 October 2020).

27. Gawryszczak, M. Europejski i Światowy Rynek Cukru. Konferencja Pokampanijna Stowarzyszenia; Techników Cukrowników: Warsaw, Poland, 15 February 2019.

28. Draycott, A.P. Sugar Beet; Blackwell Publishing Ltd.: Oxford, UK, 2006; pp. 1-8.

29. Rule, D.C.; Koch, D.W.; Jones, R.R.; Kercher, C.J. Brassica and sugar beet forages for lambs-Growth performance of lambs and composition of forage and dock-fat fatty acids. J. Product. Agric. 1991, 4, $29-33$. [CrossRef]

30. Aufrère, J.; Michalet-Doreau, B. Comparison of methods for predicting digestibility of feeds. Anim. Feed Sci. Technol. 1988, 20, 203-218. [CrossRef]

31. Aramrueang, N.; Zicari, S.M.; Zhang, R. Response surface optimization of enzymatic hydrolysis of sugar beet leaves into fermentable sugars for bioethanol production. Adv. Biosci. Biotechnol. 2017, 8, 51-67. [CrossRef]

32. Wang, Y.; Tashiro, Y.; Sonomoto, K. Fermentative production of lactic acid from renewable materials: Recent achievements, prospects, and limits. J. Biosci. Bioeng. 2015, 119, 10-18. [CrossRef]

33. Olmos, J.C.; Hansen, M.E.Z. Enzymatic depolymerization of sugar beet pulp: Production and characterization of pectin and pectic-oligosaccharides as a potential source for functional Carbohydrates. Chem. Eng. J. 2012, 192, 29-36. [CrossRef]

34. Micard, V.; Renard, C.M.G.C.; Thibault, J.-F. Influence of pretreatments on enzymatic degradation of a cellulose-rich residue from sugar-beet pulp. LWT Food Sci. Technol. 1997, 30, 284-291. [CrossRef]

35. Ward, D.P.; Cárdenas-Fernández, M.; Hewitson, P.; Ignatova, S.; Lye, G.J. Centrifugal partition chromatography in a biorefinery context: Separation of monosaccharides from hydrolysed sugar beet pulp. J. Chromatogr. A 2015, 1411, 84-91. [CrossRef]

36. Hamley-Bennett, C.; Lye, G.J.; Leak, D. Selective fractionation of sugar beet pulp for release of fermentation and chemical feedstocks; optimisation of thermo-chemical pre-treatment. Bioresour. Technol. 2016, 209, 259-264. [CrossRef]

37. Jensen, J.; Morinelly, J.; Aglan, A.; Mix, A.; Shonnard, D.R. Kinetic characterization of biomass dilute sulfuric acid hydrolysis: Mixtures of hardwoods, softwood, and switchgrass. A IChE J. 2008, 54, 1637-1645. [CrossRef]

38. Kobayashi, H.; Yabushita, M.; Komanoya, T.; Hara, K.; Fujita, I.; Fukuoka, A. High-yielding one-pot synthesis of glucose from cellulose using simple activated carbons and trace hydrochloric acid. ACS Catal. 2013, 3, 581-587. [CrossRef]

39. Chaturvedi, V.; Verma, P. An overview of key pretreatment processes employed for bioconversion of lignocellulosic biomass into biofuels and value added products. 3 Biotech. 2013, 3, 415-431. [CrossRef]

40. Yang, W.; Li, P.; Bo, D.; Chang, H. The optimization of formic acid hydrolysis of xylose in furfural production. Carbohydr. Res. 2012, 357, 53-61. [CrossRef]

41. Jung, Y.H.; Kim, K.H. Acidic Pretreatment. Pretreatment of Biomass. Proc. Technol. 2015, 3, 27-50. [CrossRef]

42. Kalogiannis, K.G.; Stefanidis, S.; Marianou, A.; Michailof, C.; Kalogianni, A.; Lappas, A. Lignocellulosic Biomass Fractionation as a Pretreatment Step for Production of Fuels and Green Chemicals. Waste Biomass Valoriz. 2015, 6, 781-790. [CrossRef]

43. Nhien, L.C.; Van Duc Long, N.; Kim, S.; Lee, M. Techno-economic assessment of hybrid extraction and distillation processes for furfural production from lignocellulosic biomass. Biotechnol. Biofuels 2017, 10, 812017. [CrossRef]

44. Tallarico, S.; Costanzo, P.; Bonacci, S.; Macario, A.; Di Gioia, M.L.; Nardi, M.; Procopio, A.; Oliverio, M. Combined Ultrasound/Microwave Chemocatalytic Method for Selective Conversion of Cellulose into Lactic Acid. Sci. Rep. 2019, 9, 1-8. [CrossRef] [PubMed]

45. Chambon, F.; Rataboul, F.; Pinel, C.; Cabiac, A.; Guillon, E.; Essayem, N. Cellulose hydrothermal conversion promoted by heterogeneous Brønsted and Lewis acids: Remarkable efficiency of solid Lewis acids to produce lactic acid. Appl. Catal. B Environ. 2011, 105, 171-181. [CrossRef] 
46. Dziugan, P.; Binczarski, M.; Modelska, M.; Witonska, I.; Sadowski, A. Recovery of municipal green bio-waste by the way of chemical transformation into valuable chemical products: Intermediates of bio polymers, green solvents and bio components of fuels. Logistyka Odzysku 2015, 3, 87-89.

47. Modelska, M.; Binczarski, M.; Kaminski, Z.J.; Karski, S.; Kolesińska, B.; Mierczynski, P.; Severino, C.J.; Stanishevsky, A.; Witońska, I.A. Bimetallic Pd-Au/SiO 2 Catalysts for Reduction of Furfural in Water. Catalysts 2020, 10, 444. [CrossRef]

48. Mariscal, R.; Maireles-Torres, P.; Ojeda, M.; Sádaba, I.; López Granados, M. Furfural: A renewable and versatile platform molecule for the synthesis of chemicals and fuels. Energy Environ. Sci. 2016, 9, 1144-1189. [CrossRef]

49. Lesiak, M.; Binczarski, M.; Karski, S.; Maniukiewicz, W.; Rogowski, J.; Szubiakiewicz, E.; Berlowska, J.; Dziugan, P.; Witońska, I. Hydrogenation of furfural over $\mathrm{Pd}-\mathrm{Cu} / \mathrm{Al}_{2} \mathrm{O}_{3}$ catalysts. The role of interaction between palladium and copper on determining catalytic properties. J. Mol. Catal. A Chem. 2014, 395, 337-348. [CrossRef]

50. Anthonia, E.E.; Philip, H.S. An overview of the applications of furfural and its derivatives. Int. J. Adv. Chem. 2015, 3, 42-47. [CrossRef]

51. Rogowski, J.; Andrzejczuk, M.; Berłowska, J.; Binczarski, M.; Kregiel, D.; Kubiak, A.; Modelska, M.; Szubiakiewicz, E.; Stanishevsky, A.; Tomaszewska, J.; et al. $\mathrm{W}_{\mathrm{x}} \mathrm{C}-\beta-\mathrm{SiC}$ Nanocomposite Catalysts Used in Aqueous Phase Hydrogenation of Furfural. Molecules 2017, 22, 2033. [CrossRef]

52. Vom Stein, T.; Klankermayer, J.; Leitner, W. Tailor-Made Fuels and Chemicals from Biomass in Catalysis for the Conversion of Biomass and its Derivatives. In Max Planck Research Library for the History and Development of Knowledge; Behrens, M., Datye, A.K., Eds.; Neopubli GmbH: Berlin, Germany, 2013.

53. Merat, N.; Godowa, C.; Gaset, A. High selective production of tetrahydrofurfuryl alcohol: Catalytic hydrogenation of furfural and furfuryl alcohol. J. Chem. Technol. Biotechnol. 2007, 48, 145-159. [CrossRef]

54. Chen, B.; Li, F.; Huang, Z.; Yuan, G. Tuning catalytic selectivity of liquid-phase hydrogenation of furfural via synergistic effects of supported bimetallic catalysts. Appl. Catal. A 2015, 500, 23-29. [CrossRef]

55. Szubiakiewicz, E.; Modelska, M.; Brzezińska, M.; Binczarski, M.J.; Severino, C.J.; Stanishevsky, A.; Witońska, I. Influence of modification of supported palladium systems by polymers: PVP, AMPS and AcrAMPS on their catalytic properties in the reaction of transformation of biomass into fuel bio-components. Fuel 2020, 271, 117584-117596. [CrossRef]

56. Rogowski, J.; Binczarski, M.; Dziugan, P.; Karski, S.; Modelska, M.; Witonska, I.; Kubiak, A. Sposób Wytwarzania Katalizatora Nanokompozytowego Katalizujacego Reakcje Redukcji Furfuralu do Alkoholu Tetrahydrofurfurylowego w Fazie Wodnej. Patent Office of the Republic of Poland PL 412726, 15 June 2015.

57. Binczarski, M.; Kaminski, Z.; Karski, S.; Kolesinska, B.; Modelska, M.; Witonska, I. Sposób Wytwarzania Mieszaniny Ciekłych Dodatków Paliwowych z Furfuralu Oraz Sposób Wytwarzania Katalizatora Palladowo-Złotowego Stosowanego w Tym Procesie. Patent Office of the Republic of Poland PL 431048, 5 September 2019.

58. Tetrahydrofurfuryl Alcohol (THFA) from Furfuryl Alcohol. Available online: https://dalinyebo.com/furfuraland-its-many-by-products/tetrahydrofurfuryl-alcohol-thfa/?fbclid=IwAR191qUuf8HhSHlOuTIIDkQ8O_ 1_ZK82XaSWI424Ea6gsX00eZIk10aZkw (accessed on 18 October 2020).

59. Hann, J.P.; Stevenson, P.A. Fuel Compositions. U.S. Patent US20070094919A1, 1 February 2007.

60. Lacome, T.; Montagne, X.; Delfort, B.; Paille, F. Diesel Fuel Compositions Containing Oxygenated Compounds Derived from Tetrahydrofurfuryl. U.S. Patent US20020053161A1, 9 May 2002.

61. Constable, G.A.; Carlson, N.L.; Heelan, G.A.; Oehr, K.H. Method of Upgrading Heavy Crude Oil. WO2008124912A1, 23 October 2008.

Publisher's Note: MDPI stays neutral with regard to jurisdictional claims in published maps and institutional affiliations. 